\title{
西太平洋の島弧・縁海系の海底熱水活動 ——現在と過去—
}

\author{
浦辺徹 郎* \\ Sea-floor Hydrothermal Activities in Western Pacific and their Relation to Ancient \\ Volcanogenic Massive Sulfide Mineralization \\ Tetsuro URABE*
}

\begin{abstract}
A compilation of 17 sulfide-bearing, sea-floor hydrothermal sites in western Pacific area was made to compare them with volcanogenic massive sulfide deposits (VMSDs) which were likely to have formed in analogous setting of ancient arc-backarc systems. Critical examination of these modes of occurrence shows that all the hydrothermal activity is limited at or above magmatic centers which occur either on backarc spreading center, in backarc rift, or on volcanic front. About half of the known localities (8 sites) are related to bimodal volcanism and are considered to be the analog of Kuroko type deposit. The other half (9 sites) are accompanied with andesitic to basaltic volcanism and are categolized into Besshi- and Cyprus-type deposits. This coincides well with the statistics that $56 \%$ of the known VMSDs belong to Kuroko type (Rona, 1988). Therefore, the present-day sea-floor mineralization well represents ancient mineralization of VMSDs now found in strata of arc-backarc affiliation.

The close spatial relationship between volcanism and hydrothermal activity suggests that both present-day and ancient deposits are of volcanogenic origin. Several lines of evidence such as isotope ratio of constituent elements (Ishibashi and Urabe, 1995) also support this conclusion. The ultimate source of these volatile elements such as oxygen, hydrogen, carbon, sulfur, nitrogen, and probably chlorine is believed to be dehydration of sediments which were subducted with oceanic plate beneath the arc-backarc systems.
\end{abstract}

\section{I. はじめに}

中生代以来, 西太平洋の大陸縁辺部は海洋プレ ートの沈み込み帯として特異な発達をとげてきた。 沈み込み帯に打ける元素循環プロセスとして, 熱 水活動が火山活動と同様の重要性を占めることが 分かって来つつあるが（たとえば，Hart and Gülen，1989），それが地質時代を通じてどのように 起こってきたのかを知る手掛かりを与えてくれる
のが，日本を初めとする島弧に典型的に産する海 底熱水鉱床である。その代表が，三波川帯・御荷 鉾帯ほかの変成帯に産し塩基性岩に伴ら別子型鉱 床と，グリーンタフ帯に産し酸性岩に伴ら黒鉱鉱 床である。前者はその生成の場が明らかではなく, 島弧でできたものとする考えと, 中央海嶺ないし 縁海拡大軸でできたものがプレートに乗って運ば れ，沈み込み帯で島弧に付加したとする考えが対 立してきた。黒鉱型鉱床はフィリピン, インドネ

\footnotetext{
* 地質調查所鉱物資源部

* Geological Survey of Japan
} 
シア,フィジーなどの島弧にも知られており（た とえば，Colley and Rice，1975)，島弧を代表す る鉱床の一つであるが，それが現在の島弧・縁海 系の中でどこに位置するかについては必ずしも意 見の一致を見ていなかった。

このような海底熱水活動により生成したと考え られる火山成塊状硫化物鉱床 (Volcanogenic Massive Sulfide Deposits : VMSD) には，この ほかにオフィオライトに伴うキプロス型鉱床があ る。本特集の荒井論文にもあるように，現在知ら れているオフィオライトの多くもまた縁海で形成 されたものと考えられ，乙かも経済的に採掘可能 な鉱床はキプロス島のそれに代表されるようにす べて縁海で生成した（Sawkins，1972）ものであ る。これは大洋中央海嶺系の熱水鉱床が, 海底に おける酸化やマントルへの沈み込みなどによって, 地質体として保存されなかった可能性が高いから かもしれないし，現在まで海底掘削 (DSDP およ び ODP）の掘削坑から鉱床が見つかっていない ことからも分かるように，確率が低い現象である せいかもしれない（浦辺，1983）。

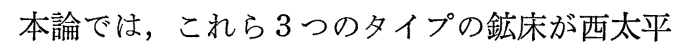
洋において現在生成しつつあるのかどうか，もし そうならその活動は火山活動にどう規制されてい るのかを考えることにする。現在と過去の海底熱 水活動の何が違うのかを明らかにすることは, 鉱 床学のみならず地球科学一般にとっても重要な課 題だからである。

\section{II. 現世の海底熱水系の種類}

1979年に中央海領で海底熱水活動が発見されて (Francheteauet al., 1979 ; Spiess et al., 1980) 以来, 世界の海底は猛烈な勢いで探査されてきた。 日本においては「しんかい2000」(1981年) および 「しんかい6500」（1989年）がタイミング良く建造 され，その利用により西太平洋において数多くの 熱水鉱床の発見および確認が行なわれた。

これまでに世界中で発見された海底熱水活動サ イトは，その兆候も含め140を数える (Rona and Scott，1993)。西太平洋には活動を停止したもの も含め27以上のサイトが知られている (Ishibashi and Urabe, 1995)。これらは，(i) 大洋中央海嶺 およびその翼部の海底火山に伴うもの，（ii）島 弧・縁海・海溝系に見られるもの，および（iii) ホットスポット火山に伴うものに大別できる。自 明のことであるが，西太平洋に㧍いてはオースト ラリアと南極大陸の間にある環南極海嶺を除くと （i）の大洋中央海嶺は存在しない。またハワイの ロイヒ海山やタヒチのマクドナルド海山で代表さ れる（iii）のホットスポット火山は, 熱水鈗床を 生成する好適な条件である高温の熱源, 高い透水 率など（Rona，1988）を備えているにもかかわ らず，硫酸塩ないし硫化物を主とする高温の熱水 活動を伴っていない (Ishibashi and Urabe, 1995)。その理由は不明であるが，ホットスポッ 卜は現在までに分かっているところでは鉱床学的 に不毛である。

よって西太平洋の海底熱水活動はすべて島弧・ 縁海・海溝系に見られるものである。西太平洋に 見られるこれらの熱水活動を大まかに温度の低い ものから区分すると表 1 のようになる。熱水の地 下での沸騰や，堆積物との反応などを考虑する必 要があり, 熱水の化学は単純に温度だけで規定す ることはできないので (Ishibashi and Urabe, 1995)，これは大まかな目安である。また一つの サイトの温度はしばしば大きく変化し, それらス テージの異なる生成物が重なって産している場合 があるので注意が必要である。一般的にいって低 温から高温に向けて, 沈殿する鉱物が酸化物, 硫 酸塩, 硫化物と変化する。鉱物の溶解度の実験か らも支持されるよらに, 高温の熱水のみが重金属 を溶解・沈殿しうるからである。経験的にいって 低温の活動は銅を伴わず, 高温 $\left(350^{\circ} \mathrm{C}\right.$ 以上) の ものは黄銅鉱などの銅硫化物を伴う。また酸性火 山に伴ら熱水は鉛および重晶石を産することが多 い。以下ではこれらの，一部硫化物を伴ら，ない し硫化物を主とする高温の熱水活動のみに焦点を 当てることにする。

\section{III. 西太平洋における海底熱水活動}

西太平洋には世界の縁海の75\%が集中しており (Tamaki and Honza, 1992), 現在までに発見 
表 1 熱水の温度により区分した西太平洋の海底熱水活動

Table 1 Classification of sea-floor hydrothermal activity in Western Pacific based on its estimated temperature

\begin{tabular}{|c|c|c|c|c|}
\hline 熱 水温度 & 代表的自生鉱物 & 地質学的な「場」 & 表 & 文献 \\
\hline (a) $<10^{\circ} \mathrm{C}$ & なし（cold seepage） & 沈み込み帯前弧域や堆積盈地など & 南海トラフ, 銭洲海嶺 & 1 \\
\hline (b) $<50^{\circ} \mathrm{C} ?$ & 鉄・マンガン酸化物 & 火山体側斜面，高温熱水域周辺など & 小笠原海形海山 $\mathrm{KM}$ ピーク & 2 \\
\hline (c) $50 \sim 100^{\circ} \mathrm{C}$ & 石膏，鉄水酸化物沈殿 & 火山島周辺の浅海ないし浅い海底火山 & ラバウル，薩摩硫黄島 & 3 \\
\hline$(d) \leqq 150^{\circ} \mathrm{C} ?$ & シリカ, 重晶石チムニー & 背弧リフトの火山，島弧の火山 & 小笠原スミス・リフト & 4 \\
\hline (e) $200 \sim 300^{\circ} \mathrm{C}$ & 硬石膏, 重晶石, 硫化物 & $\begin{array}{l}\text { 縁海拡大軸, 背弧リフトの火山, 島弧 } \\
\text { の火山 }\end{array}$ & 北フィジー海盈 & 5 \\
\hline (f) $220 \sim 400^{\circ} \mathrm{C}$ & 銅, 鉛, 覀鉛硫化物 & $\begin{array}{l}\text { 縁海拡大軸, 背弧リフトの火山, 島弧 } \\
\text { の火山 }\end{array}$ & ラウ海盈バルファー海嶺 & 6 \\
\hline
\end{tabular}

主な文献 : 1. Taira and Pickering (1991)，2. Usui et al. (1986), 3. Stuben et al. (1992),

4. Urabe and Kusakabe (1990), 5. 浦辺ほか (1990), 6. Fouquet et al. (1993).

詳しくは Ishibashi and Urabe (1995) 参照.

熱水の化学組成はさまざまな要因により左右されるし，熱水系は短期間のうちに進化しその温度が変動することが多 いので，温度の值は単なる目安に過ぎない。

されている27カ所の島弧・縁海系の熱水活動はす ベてこの地域に存在する（Ishibashi and Urabe, 1995)。そのらち硫化物を伴うことが確認されて いるのは17カ所である（図 1 , 表 2 )。これらのテ クトニックな場所を悠密に規定するのは難しいが, 一般化すると縁海拡大軸に位置するものが 9 力所, 背弧リフトが 2 カ所, 火山フロント上に 6 カ所存 在する (図 2 )。火山岩の組成で分類すると, 8 カ所はデイサイトないし流紋岩火山活動に伴われ， 9 カ所は玄武岩ないし安山岩に伴われている。つ まり伴われる火山活動を元にした簡略な区分でい えば，西太平洋で発見されている現世の鉱床の約 半分は黒鉱型であり，残りの半分は別子型かキプ ロス型といらことになる。さらに沖繩トラフのよ うに厚い堆積物が存在する場所 (Halbach et al., 1989）を含め，硫化物を産する高温熱水活動は火 山の組成によらず，すべて火山体の直上に限られ ている。この事実は高温熱水活動の存在にマグマ 活動が不可欠であるとする考え方（たとえば， Urabe，1987）に強い支持を与えている。

では火山以外の所にも高温熱水鉱床が存在する 可能性はあるのであろらか?つまり，上記の熱水 活動と火山活動との密接な関係は, これまでの精 查地域が海底火山周辺に偏っていたためという人 為的な要素によっているのであろうか?この問い に答えるのはきわめて難しいが，幾つか手脚かり
になる事例をあげてみよう。伊豆・小笠原弧の岩 石や堆積物は，地質調查所の特別研究「海底熱水 活動に伴う重金属資源の評価手法に関する研究」 （1984-1989）などにより広汎な採取・分析が行な われた（たとえば，Yuasa et al., 1991; Nishimura and Murakami, 1988)。しかしマンガン酸 化物を除いて表 2 以外の熱水堆積物は見つからな かった。日仏 KAIKO-II 計画 (Le Pichon et $a l ., 1987)$ にる Nautile 号潜航調查や, 日米小笠 原・マリアナ弧 Alvin 号潜航調査 (Taylor et al., 1990) を初めとして, 西太平洋で行なわれた 潜航調查は学際的なものが多く必ずしも熱水現象 を目的としていなかったが，沈み込み帯や前弧域 での低温の涌水現象 (Taira and Pickering, 1991) を除くと，火山地带以外では熱水活動は発見され ていない。熱水活動周辺は，さまざまな形で生物 活動の異常によって修飾されており（太男， 1988)，他目的の潜航でも熱水活動が見過ごされ る可能性は低い。逆に熱水活動を目的とした調査 でも，熱水発見の陰に数多くの「空振り」の潜航 があることが一般的で，周辺地域の探査もなされ ていることが多い。つまり上記の火山中心と熱水 噴出之の密接な関係は，これまで西太平洋の島 弧・縁海系のさまざまな場においてなされてきた 調査活動を基に，高い確度をもって得られた結論 といえる。 


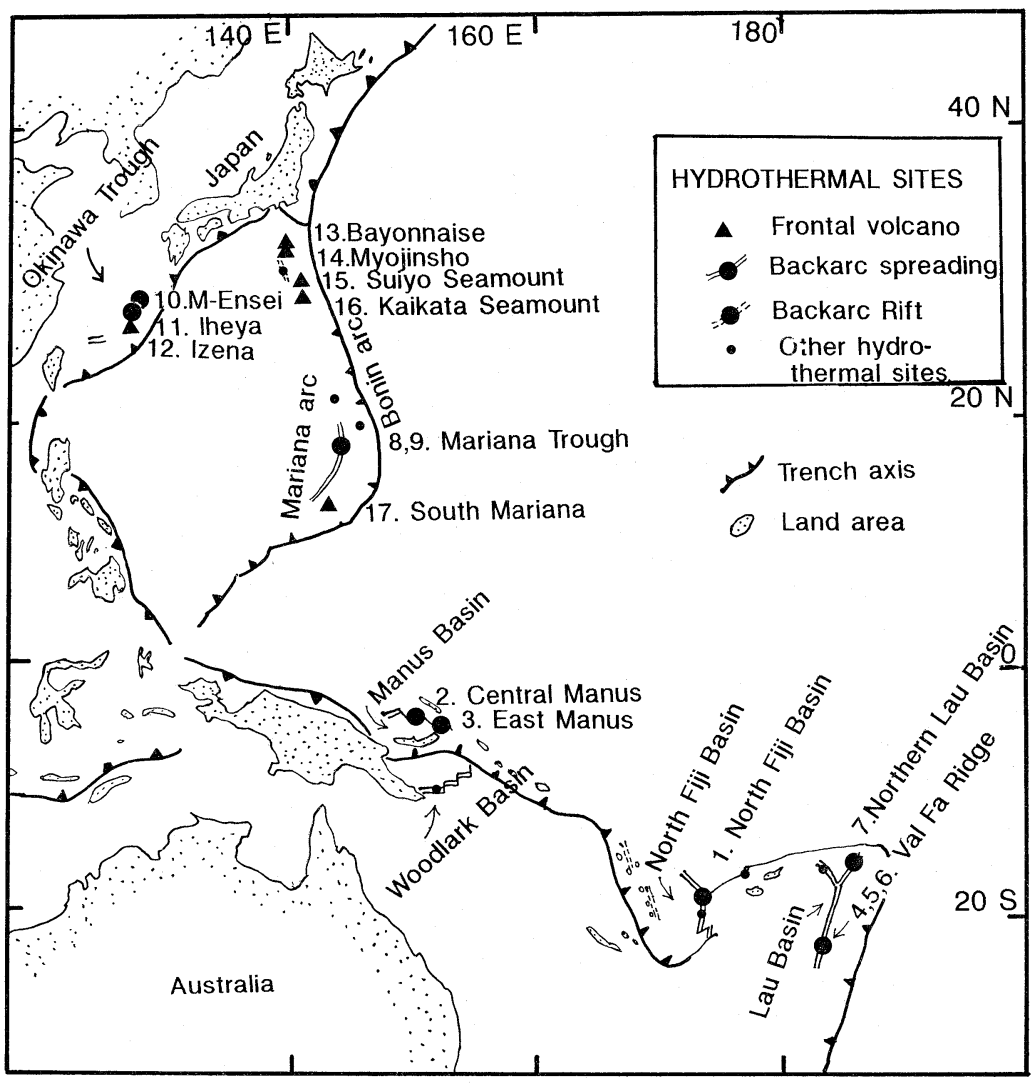

図 1 西太平洋において確認されている硫化物を伴う海底熱水サイト サイト番号は表 2 参照. その他の熱水サイト (小丸) は酸化物, 炭酸塩, 硫 酸塩, シリカなどを伴うもの. (Ishibashi and Urabe, 1995を簡略化)

Fig. 1 Known sulfide-bearing hydrothermal sites superimposed on simplified tectonic map of the western Pacific

Site numbers correspond to those in Table 2. "Other hydrothermal sites" may have either oxides, carbonates, sulfates, or silica, but have no sulfides. (modified after Ishibashi and Urabe, 1995)

\section{IV. 現世の熱水に見られるマグマ起源物質}

海嶺軸の玄武岩マグマ溜まりの上面の深さは, 拡大速度に比例して浅くなる。拡大速度の遅い大 西洋中央海嶺ではマグマ溜まりは $7 \mathrm{~km}$ 程度の樑 さにあると推定されているが，速度の速い（年間 $5 \mathrm{~cm}$ 前後) 北部東太平洋海膨では平均深度 1,500 $\mathrm{m}$ に見られる。さらに年間 $15 \mathrm{~cm}$ の非常に速い拡 大速度を持つ南部東太平洋海膨では, 海 底下 900 1,200 m の深度にマグマ溜まりが存在して いる (Detrick et al., 1992)。Kinoshita (1990) によれば，沖繩トラフの伊是名海穴（JADE サ
イト）における熱水対流セルの大きさは，深さお よび半径約 $1 \mathrm{~km}$ であるという。ここの堆積物 （軽石とシルトの互層）の厚さは不明であるが, 異 常に高、熱流量から計算して, 海底下 $1 \mathrm{~km}$ 程度 に（岩脈状の?）酸性マグマが存在する可能性が ある。よってここでは上昇してくる熱水は, 起源 はともかくとして火山岩とそれを覆う堆積物の両 者と反応していると考えられ，熱水の化学組成は それらとの反応に規制されるであろう。その他の 地域では対流セルの大きさが堆定されておらず詳 しくは分からないが，大洋中央海嶺の類推でいえ ば深さ $1.5 \mathrm{~km} \sim 6.5 \mathrm{~km}$ 程度であろら（Cathles， 
表 2 西太平洋の島弧・縁海系に見られる硫化物を産する熱水活動（Ishibashi and Urabe，1995 を簡略化）

Table 2 Sulfide-bearing hydrothermal activity in arc-backarc systems in Western Pacific (Modified after Ishibashi and Urabe, 1995)

\begin{tabular}{|c|c|c|c|}
\hline 地 域 名 & サイト名 & 水深 $(\mathrm{m})$ 伴う火成岩 & 鉱物 学的特徵 \\
\hline \multicolumn{4}{|l|}{ 〔縁海拡大軸〕 } \\
\hline 1. 北フィジー海盈 & White Lady & 1,980 玄武岩 & $\begin{array}{l}290 \text { anhy } \text { wurz } \\
\text { w. マウンド中に py, mc, cp, sph, }\end{array}$ \\
\hline 2. マヌス海盈中央部 & Vienna Woods & 2,500 玄武岩 & - sph, wurz, py, mc, cp, gn, ba, anhy \\
\hline 3. マヌス海盈東部 & PACMANUS & 1,650 デイサイト & - anhy, cp, bo, tenn, sph \\
\hline 4. バルファー海嶺 & Vai Lili & 1,700 流紋岩～玄武岩 & 400 py, cp, mc, sph, ba, tenn, gn, Au \\
\hline 5. バルファー海嶺 & Hine Hina & 1,900 安山岩〜゙サイト & 40 py, cp, sph, ba Mn-oxide がコーティング \\
\hline 6. バルファー海嶺 & White Church & 1,950 玄武岩 & 一 ba に富む. sph, gn, tenn, cp, po, electrum \\
\hline 7. 北部ラウ海盈 & Papatua & 2,100 玄武岩 & - wurz, py, cp, ba, silica, Mn-oxide \\
\hline 8. マリアナ・トラフ & Alice Spring & 3,600 玄武岩 安山岩 & 287 ba に富む. sph, gn, cp, py \\
\hline $\begin{array}{l}\text { 9. マリアナ・トラフ } \\
\text { [背弧リフト] }\end{array}$ & Central Mariana & 3,675 玄武岩～安山岩 & ? sph, ba, silica \\
\hline 10. 南奄西海丘 & Minami-Ensei & 700 酸性岩? & $\begin{array}{l}278 \text { anhy に富む. sph, wurz, tetra, cp, gn, py, } \\
\text { bo, cov }\end{array}$ \\
\hline 11. 伊平屋海嶺 & CLAM (Iheya) & 1,400 玄武岩 & $\begin{array}{l}220 \text { calcite に富む. anhy, wurz, po, gn, cp, } \\
\text { argentite }\end{array}$ \\
\hline \multicolumn{4}{|l|}{ [火山フロント] } \\
\hline 12. 伊是名海穴 & JADE (Izena) & 1,350 デイサイト & $\begin{array}{l}320 \text { sph, tetra, gn, ba, cp, py, wurz, anhy, } \\
\text { stibnite }\end{array}$ \\
\hline $\begin{array}{l}\text { 13. 北べョネーズカル } \\
\text { デラ }\end{array}$ & Bayonnaise & 1,400 デイサイト & - ba. py, cp, sph, tetra-tenn \\
\hline 14. 明神礁カルデラ & Myojinsho & 1,100 デイサイト & - ba, py \\
\hline 15. 水矅海山 & Suiyo seamount & 1,370 デイサイト & $311 \mathrm{cp}$, sph, anhy, ba \\
\hline 16. 海形カルデラ & Kaikata & 930 玄武岩～安山岩 & - py, cp?, sph \\
\hline 17．南部マリアナ & Snail Haven & 1,470 玄武岩 & 202 anhy, ba, sulfides \\
\hline
\end{tabular}

[田各号〕 sph : sphalerite, gn : galena, py : pyrite, cp : chalcopyrite, mc: marcasite, wurz: wurtzite, tenn : tennantite, tetra : tetrahedrite, bn : bornite, cov : covellite, silica : amorphous silica, ba: barite, anhy : anhydrite, $\mathrm{Mn}$ : manganese

1993)。

拡大が進んだ背弧海盈の拡大軸の鉱床は，中央 海嶺のそれとほとんど化学組成が類似しているこ とが考えられる。というのも，大洋中央海嶺の鉱 床でも縁海拡大軸の鉱床でも, 海洋地殼を構成す る岩石にほとんど差がないからである。実際, Ishibashi and Urabe (1995) は別子型, 北フィ ジー海盈, マヌス海盈の鉱石の化学組成が大洋中 央海嶺のそれと類似することを指摘した。しかし， 島弧地殼の上に発達し，異なったマグマの組成を 持つ鉱床では化学組成が異なることが予想される。 実例を見てみると, ウラ海盈, 沖繩トラフ（伊是 名海穴および南奄西海丘) のそれは黒鉱の化学組
成と類似しているが，これら酸性岩マグマに伴う 鉱床ばかりでなく，玄武岩に伴うマリアナ・トラ フのそれも黒鉱に類似している。ここの玄武岩 は沈み込み带起源の元素を濃集した特異なもの (Stolper and Newman，1992）なので，それに伴 ら鉱床の元素比が島弧の火山岩に伴う黒鉱と類似 しているのであろら。

一方, 明らかに堆積物起源と思われる成分もあ る。Gamo et al. (1991) は, 沖繩卜ラフ伊平屋海 嶺の CLAM サイトの熱水の alkalinity が高 く, アンモニアに富み, 硫酸塩の硫黄同位体比が ${ }^{34} \mathrm{~S}$ に富むことは，すべて堆積物中の有機物との 反応で説明できることを明らかにしている。また 


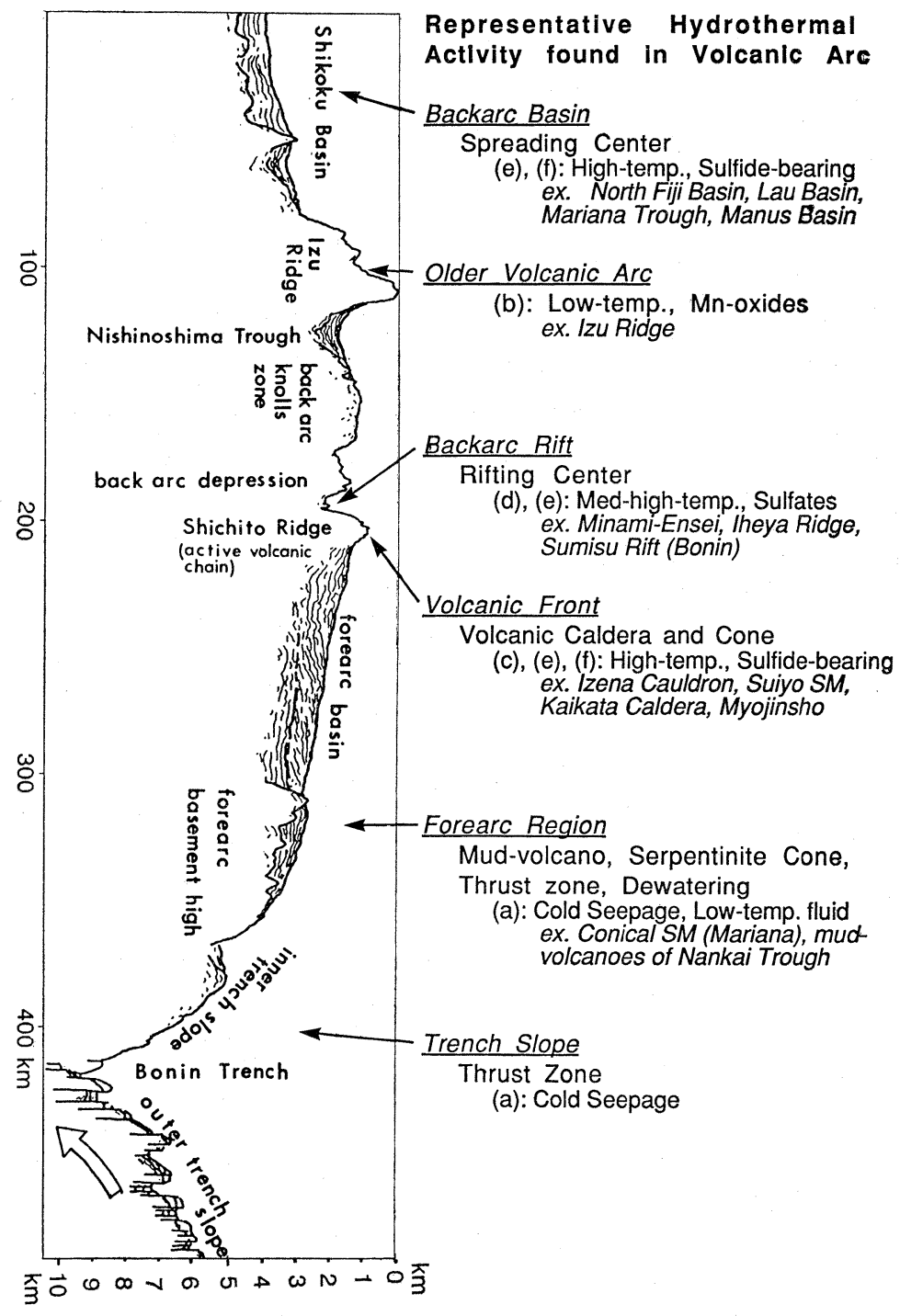

図 2 伊豆・小笠原島弧海溝系の断面 (北緯31度 : Honza and Tamaki, 1985 による）に投影した各種（a〜f: 表 1 参照）の熱水活動の産状

それらの熱水活動が必ずしもこの断面の場所に見られるわけではない. 地質断面は縦方向に拡大してある.

Fig. 2 Modes of occurrence of hydrothermal activity in relation to tectonic units in trench-arc-backarc system

Geologic cross section of Izu-Ogasawara (Bonin) arc along $31^{\circ} \mathrm{N}$ is used (after Honza and Tamaki, 1985) to represent typical arc system. Note vertical exaggeration. The sites of hydrothermal activity are hypothetical and are not necessarily found along this particular section. The classification of hydrothermal activity from (a) to (f) denote those given in Table 1 . 
伊是名海穴熱水の高、濃度のホウ素の起源は, 堆 積物である可能性が高い (Ishibashi and Urabe, 1995)。

反対にマグマ起源の流体が大きく寄与している 成分として, 硫黄, 炭素およびヘリウムがある。 現世の熱水鉱床の硫黄の同位体比はすべて $0-8$ $\%$ の範囲に入り，マグマ源硫黄に一致する（Ishibashi and Urabe, 1995)。沖繩卜ラフの 2 カ所で 液体二酸化炭素の “水滴” が海底から泡状に噴出 し，ガス・ハイドレートに変化する現象が発見さ れている（Sakai et al., 1990）が，これらの二酸 化炭素の炭素同位体比は高温熱水中のそれと同じ で，そのいずれもがマグマ起源と考えられている （千葉ほか 1992）。液体二酸化炭素の方は，海底 下のマグマ溜まりの表面から拡散した二酸化炭素 ガスが，空陌率の高い堆積物中に保持されたもの であるかもしれない。いずれにせよ熱水系の下に 揮発性成分に富む背弧のマグマの存在を強く示唆 する事実である。詳しいことは別稿 (Ishibashi and Urabe，1995）にまとめてあるので省略する が，熱水中のヘリウム同位体比についても火山ガ スに相当する值が得られている。

\section{V. 沈み込み帯において発生する流体の寄与}

沈み込み帯において沈み込んだ堆積物中の元素 が，島弧マグマ，火山ガスないし低温の流体とし て地表に再循環してくるかどうかは地球科学上の 重要な問題の一つである。Morris et al. (1989) は，高層大気中で宇宙線により酸素と窒素から作 られる同位体である ${ }^{10} \mathrm{Be}$ を用いてその寄与の見 積りを行なった。海水中に溶け込んだ ${ }^{10} \mathrm{Be}$ は海嶺 玄武岩 (MORB) の $10^{4}$ 倍以上堆積物に吸着され 易いため (Valette-Silver et al., 1985), 島弧火 山岩中の ${ }^{10} \mathrm{Be}$ 量は堆積物の寄与に対してはきわ めて敏感であるのに対し，プレートを構成する火 成岩の影響を受けない。さらに ${ }^{1 \wedge} \mathrm{Be}$ は半減期が 1.5 百万年であるので, 鮮新世以後の堆積物の 影 響のみを知ることができる。Morris et al. (1989) によると MORB 中の ${ }^{10} \mathrm{Be}$ は検出限界以下であ

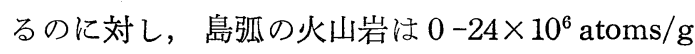
と高い值を持ち, 大きな堆積物の寄与が窥える。
全島弧の火山岩の生産レートは $1.1 \mathrm{~km}^{3} /$ 年 と試 算されるので, $2-8 \%$ の堆積物が島弧マグマに 混入しているのなら, 堆積物の11-44％は地表に 還流することになる（Morris et al., 1989)。

さらに Kita et al. (1993) は, 空気からの 混入による影響を除外した東北日本の火山ガス端 成分が，九州地区のそれに比べて約 10 倍高い $\mathrm{N}_{2}$ / Ar 比を持つことから, 沈み込み帯の上に存在す る東北日本の島弧マグマに大きな堆積物由来の窒 素の寄与があり, 沈み込み帯が到達していない西 南日本の島弧マグマにそれがないことを明らかに した。また Giggenbach（1992）によると，太平 洋周辺域の沈み込み帯の火山に伴う火山ガスや地 熱水の酸素・水素同位体組成は，堆積物中に取り 込をれた海水を起源としている。彼によれば $98 \%$ 以上の “andesite water” は二酸化炭素, 窒素, および塩素と同様，このよらにしてもたらされた “devolved seawater”と考えられる。しかし島弧 マグマ自体の組成に堆積物の寄与があるかどうか は論争のあるところで, 非常に少ないとする説 （たとえば, Saunders et al., 1991）と大きいとす る説（たとえば, Stolper and Newman, 1992) が 対立している。

現在地球上には海嶺の総延長の約半分に相当す る $37,000 \mathrm{~km}$ の沈み込み帯があり, 沈み込みの平 均速度は $80 \mathrm{~km} / \mathrm{Ma}$ とされている (Reymer and Schubert，1984)。そこでプレート上に幅 $1 \mathrm{~km}$, 深さ $0.3 \mathrm{~km}$ のベーズンが $20 \%$ の割合で覆ってい たとすると, 百万年当たり沈み込む堆積物量は約 $2 \times 10^{5} \mathrm{~km}^{3}$ と計算できる。その中の有機炭素含 有量を控えめに平均 $0.5 \%$ と見積ると, 沈み込む有 機炭素の総量は $5 \times 10^{8}$ ton $/ \mathrm{yr}$ と計算される。こ れはメタンとして中央海領の熱水系から放出され ている炭素量 $6.6 \times 10^{6}$ ton $/ \mathrm{yr}$ の75倍に相当する (浦辺，1993）。陸上の火山から放出される「マグ マ源」メタンの量は全く分かっていないが，固体 地球からの二酸化炭素の放出量（全地 球 で1.3$1.8 \times 10^{8}$ ton $/ \mathrm{yr}$ ） は陸上の火山ガスの方が海底熱 水系に比して約 3 倍程度多いので, もし陸上でも 海底と同じ二酸化炭素/メタン比（約100）が変わ らないと仮定するなら，陸上メタンの放出フラッ 
クスは約 $2 \times 10^{\eta}$ ton $/ \mathrm{yr}$ となる。これらの数字は 今後検討の余地があるが，いずれにせよ沈み込み 帯において炭素は非常に“大超”で，火山ガスな いし島弧の海底熱水系などで放出されている量は, 沈み込み量に比べてごくわずかである。西太平洋 の海底熱水系が大洋中央海領のそれに比して, 非 常にガス成分に富む (Ishibashi and Urabe, 1995）ことは，この計算からも十分らなずける。

また黒鉱でも現世の鉱床でも，火山中心と鉱化 中心が一致しており, 酸性マグマの上昇口を利用 して熱水が上昇している。陸上の島弧活火山では 火山ガス中や地熱水の $\mathrm{H}_{2} \mathrm{O}$ に大きなマグマ水の 寄与が知られているので (Giggenbach，1992), 海底においても同様のことが起こっていることが 強く示唆される。西太平洋の海底熱水系は, 中央 海頙のそれに比ベマグマの寄与がより明解に見ら れ，結果として生成した鉱床中にもその影響があ ると考えられるのである。

\section{VI. 火山活動と鉱化作用}

黒鉱鉱床はこれまで述べてきたように酸性火山 活動に伴うが，マグマ発達史的な視点を加えると リフティングに関連したバイモダル火山活動に伴 らといったほうが正確な表現となる(Urabe,1987)。 秋田県北鹿地方の黒鉱鉱床をもたらした酸性火山 活動は，例外なく溶岩円頂丘の生成か，発泡度の ごく低い角礫よりなる火山角䃯岩の堆積で始まっ ている。その上に, 砕屠岩の挟みを持つことなく 黒鉱鉱体が乗っており，噴火活動と鉱化作用との 間に時間間隙がなかったことを示している。鉣化 活動が終了した後に海底を覆った堆積物, つまり 上盤側の岩石には，厚い軽石流が見られる場合， 玄武岩の活動がある場合, および厚い泥岩の堆積 がある場合の 3 通りがある。Urabe（1987）はイ エローストン・カルデラに拉けるバイモダル火山 活動からの類推により，島弧地殼のリフティング, マントル内での立武岩マグマの発生と上昇, 玄武 岩の熱によるリフト帯の下部地殼の溶融と酸性プ ルトンの発生, 酸性マグマキューポラの上昇と溶 岩円頂丘の生成，マグマ源鉱液の分離と黒鉱の生 成, リフティングの終了に伴う海底の浅化, プル
トンの封圧の減少による揮発性成分の発泡と爆発 的噴火，それによる厚い軽石流の発生，プルトン の固化とそれを貫く玄武岩マグマの噴出，という マグマ・熱水系進化過程を提案した。

このモデルは現世の海底熱水釷化作用にも適用 できるものと思われる。バイモダル火山活動が知 られている例として, 表 2 の沖繩トラフ伊是名海 穴の他に，硫化物は見られないが黒鉱の鉄石英に 類似した化学組成を持っシリカ・チムニーと重晶 石を産する小笠原スミス背弧リフトの例がある (Urabe and Kusakabe, 1990)。後者では気泡に 富む枕状玄武岩溶岩を突き破って直径 $500 \mathrm{~m}$ 程度 の流紋岩の溶岩円頂丘が噴出しており，その頂上 近くに重晶石・シリカチムニーが林立している。 ラウ海盈のバルファー海嶺でも, バイモダル火山 活動に鉱床が密接に伴っている (Fouquet et al., 1993)。伊是名海穴では 2 個の流紋岩質の溶岩 円 頂丘が鉱床近傍に見られているが（中村光一，私 信)，玄武岩溶岩は見っかっていない。小笠原の 水曜海山, バルファー海嶺の一部も酸性火山岩の みが知られている。

注目に值するのは，これら酸性岩に伴う海底熱 水鉱床が他のものに比べて鉱量が大きいというこ とである。いずれの鉱床においても具体的な推定 をするだけのデータは揃っていないが，伊是名海 穴, 水曜海山, バルファー海嶺のものは比較的大 規模であり，玄武岩に伴うものは小規模である傾 向がある。先に述べたように，西太平洋で発見さ れている現世の海底熱水鉱床の約半分は黒鉱型で あり，残りの半分は別子型かキプロス型であるが， この比率は陸上の VMSD のうち, 黒鉱型のもの が約56\%を占めるといら統計結果（Rona，1988) とよく符合する。さらに VMSD のらち玄武岩に 伴らものが $17 \%$, 鉱量も 3,000 万トンどまりで あるのに対し，黒鉱型のものは鉱量も最高 2 億 3,000万トンに達するという事実も上記の観察と 整合的である。やはり現世の海底熱水鉱床は，ほ ぼ地球史を通じて生成されてきた VMSD の現代 版といってょく, その頻度や産状も地質時代を通 ビて斉一的に解釈できそうである。 


\section{VII. 鉱床の保存}

黒鉱型 VMSD は別名を層準規制型塊状硫化物 鉱床 (starata-bound massive sulfide deposits) と 呼ばれる。これはこの種の鉱床がある特定の層準 に偏って見られ，他の層準に見られない例が多い からである。たとえば北鹿地域の黒鉱鉱床は 15 $\mathrm{Ma}$ に限られ, その上位の酸性火山岩には伴われ ない。この原因については, その時代が酸性火山 活動のピークに相当し，さらに細かくいえば同地 域の黒鉱が火山砕原岩などの特有な噴火様式にの み伴われる (Urabe, 1987) ことなどが，説明とし てあげられている。

しかし, 熱水性硫化物性成後地質体として保 存されなければ鉱床にならないという要素も忘れ てはならない。Mitchell and Garson (1981) は 現世の縁海において鉱化作用が発見されない （注：これは明らかに䛊りであるが）のは, 現在火 山弧と大陸の間にできた縁海がないため，火山灰 と研屑物により金属鉱床が覆われ，保存される可 能性がないためと考えたほどである。梶原 (1983) は，嫌気的な水塊に覆われたベーズンに掞いて硫 化物が保存される可能性を指摘しているが，現世 の鉱床が火山中心に伴われることと，これらのこ とは矛盾する。というのも, 火山中心は温度が高 く, マグマの噴出が起こるので, 周囲の海底に比 べて水深が浅いことが一般的だからである。この ような地形的な高まりに嫌気的な環境を作ったり, 堆積物のカバーを乗せることは難しい。実際, 堆 積物に覆われない大洋中央海嶺の場合, 死んだチ ムニーが酸化されて赤褐色の酸化鉄塊になってい ることがしばしば観察される。

そこで考えられるのが火山カルデラないし山頂 火口である。これらは極地的に凹地を作っている ので, 保存のための条件を満たしやすい。カルデ ラ底に熱水の余波があるだけでも，極地的な還元 状態が作りだせるし, カルデラ壁からの崖錐堆積 物の供給により鉱床が速やかにカバーされること が期待できるからである。実際このような条件は 海形カルデラ, 明神礁カルデラなどで実現されて いる可能性がある。黒鉣がカルデラに伴うという
古くて新しい説の正当性は，そこが生成の場とし てのみでなく，保存の場としても好適であること によっているものと考えられる。

\section{VIII. 結 論}

西太平洋海域には 17 の硫化物を伴う海底熱水活 動サイトが知られている。そのうち, 縁海拡大軸 に位置するものが 9 力所, 背弧リフトが 2 力所, 火山フロント上に 6 カ所存在する。熱水活動の約 半数は酸性火山活動に伴うもので, 残りは塩基性 火山活動に伴われている。前者は生成中の黒鉱鉱 床といえるもので, 後者はキプロス型ないし別子 型鉱床に分類される。これら陸上の VMSD の うち各タイプの鉱床が占める割合は現世の海底熱 水活動の分類とほぼ同じで, VMSD が現在の海 底熱水活動と同様の生成プロセスで, 地質時代の 島弧・縁海系で形成されるものとする考えが支持 される。

これら硫化物を産する高温熱水活動はすべて火 山体の直上に限られており, 高温熱水活動の存在 にはマグマ活動が不可欠であるといえる。また熱 水の起源としてマグマ水が有力である。水, 硫黄, 炭素, 塩素, ヘリウム, および窒素などの成分で は, 沈み込み帯の堆積物起源の成分の寄与が見ら れ，それら堆積物起源元素がいったん島弧・縁海 のマグマに取り込まれ，さらにマグマから分離放 出されたマグマ性熱水に溶存して上昇し, 鉱床を 形成したものであることが分かる。できた鉱床が 保存される場としては火山カルデラが最も好適で あり，これらが黒鉱鉱床がカルデラに伴ら一つの 理由であろう。

\section{謝 辞}

西太平洋に抒いて, 日本人の手により数多くの熱水活 動が発見された背景には，2つの「しんかい」のオペレ ーション技術が，短期間で世界最高の水準に達したこと の寄与が大きい。海洋科学技術センターの関係者の不断 の努力を称えると同時に, これまでの航海でお世話にな った司令以下オペレーション・チームの方々, 船長以下 乗組員の方々に深く感謝したい。この小論恃石橋純一郎, 川幡穂高, 篠原宏志, 中村光一の各博士との議論から多 くを得て書かれた。これらの人に感謝する。 


\section{文 献}

Cathles, L. M. (1993) : A capless $350^{\circ} \mathrm{C}$ flow zone model to explain megaplumes, salinity variations, and high-temperature veins in ridge axis hydrothermal systems. Econ. Geol., 88, 1977-1988.

千葉 仁・酒井 均・滆生俊敬・石橋純一郎・中島和夫 ・南 秀樹・土橋 史 (1992) : 南奄西海丘で涌出し ている気泡の化学・同位体組成. 第 8 回しんかいシン ポジウム報告書, 海洋科学技術センター, 81-89.

Colley, H. and Rice, C. M. (1975): A kurokotype ore deposit in Fiji. Econ. Geol., 70, 13751386.

Detrick, R. S., Harding, A. J., Kent, G. M., Orcutt, J. A., Mutter, J. C. and Buhl, P. (1992) : Seismic structure of the southern East Pacific Rise. Science, 259, 499-503.

Fouquet, Y., von Stackelberg, U., Charlou, J. -L., Erzinger, J., Herzig, P. M., Muhe, R. and Wiedicke, M. (1993) : Metallogenesis in back-arc environments: The Lau Basin example. Econ. Geol., 88, 2154-2181.

Francheteau, J., Needham, H. D., Choukroune, P., Juteau, T., Ségret, H., Ballard, R. D., Fox, P. J., Normark, W., Carranza, A., Cordova, D., Guerrero, J., Ranjin, C., Bougault, H., Gambon, P. and Hekinian, R. (1979): Massive deep-sea sulfide ore deposits discovered on the East Pacific Rise. Nature, 277, 523-528.

Gamo, T., Sakai, H., Kim, E. S., Shitashima, K. and Ishibashi, J. (1991): High alkalinity due to sulfate reduction in the CLAM hydrothermal field, Okinawa Trough, Earth Planet. Sci. Lett., 107, 328-338.

Giggenbach, W. F. (1992): Isotopic shifts in waters from geothermal and volcanic systems along convervent plate boundaries and their origin. Earth Planet. Sci. Lett., 113, 495-510.

Halbach, P., Nakamura, K. I., W ahsner, M., Lange, J., Sakai, H., Kaeselitz, L., Hansen, R. D., Yamano, M., Post, J., Prause, B., Seifert, R., Michaelis, W., Teichmann, F., Kinoshita, M., Maerten, A., Ishibashi, J., Czervinski, S. and Bulm, N. (1989): Probable modern analogue of Kuroko-type massive sulphide deposits in the Okinawa Trough back-arc basin. Nature, 338, 496-499.

Hart, S. R. and Gülen, L. eds. (1989) : Crust/ mantle recycling at convergence zones. NATO ASI Series C-258, Kluwer Academic Publ., Bonn, $279 \mathrm{p}$.

Honza, E. and Tamaki, K. (1985): Bonin Arc. In Nairn, A. E. M., Stehli, F. G. and Uyeda, S. eds.: The ocean basins and margins. The Pacific Ocean Series, Plenum Co., New York, 459-502.
Ishibashi, J. and Urabe, T. (1995): Hydrothermal activity related to arc-backarc magmatism in western Pacific. In Taylor, B. ed. : Backarc basins. Plenum Press, New York (in press).

梶原良道 (1983)：黑鉱鉱床生成の地史学的意義一一黒 鉱・石油同源説. 鉱山地質 (特別号)， 11，289-304.

Kinoshita, M. (1990): Heat fiow anomaly in some Western Pacific trench-arc-backarc systems associated with interstitial water circulation. $\mathrm{Ph}$. D.Thesis, Univ. Tokyo, 74 p.

Kita, I., Nitta, K., Nagao, K., Taguchi, S. and Koga, A. (1993): Difference in N2/Ar ratio of magmatic gases from northeast and southwest Japan: New evidence for different states of plate subduction. Geology, 21, 391-394.

Le Pichon, X., Kobayashi, K., Cadet, J. P., Iiyama, T., Nakamura, K., Pautot, G. and Renard, V. (1987) : Project Kaiko. Earth Planet. Sci. Lett., 83, 181-375.

Mitchell, A. H. G. and Garson, M. S. (1981): Mineral deposits and global tectonic settings. Academic Press, London, $405 \mathrm{p}$.

Morris, J., Tera, F., Sacks, I. S., Brown, L., Klein, J. and Middleton, R. (1989) : Sediment recycling at convergent margins: Constraints from the cosmogenic isotope ${ }^{10} \mathrm{Be}$. In Hart, S. R. and Gülen, L. eds.: Crust/mantle recycling at convergence zones. Kluwer Academic Publ., 81-88.

Nishimura, A. and Murakami, F. (1988): Sedimen. tation of the Sumisu Rift, Izu-Ogasawara Arc. Bull. Geol. Surv. Japan, 39, 39-61.

太田 秀 (1988): 海底熱水系と生物過程. 地球化学, 22, 87-95.

Reymer, A. and Schubert, G. (1984): Phanerozoic addition rates to the continental crust and crustal growth. Tectonics, 3, 63-77.

Rona, P. A. (1988): Hydrothermal mineralization at oceanic ridges. Canad. Mineral., 26, 431-465.

Rona, P. A. and Scott, S. D. (1993): Preface for a special issue on sea-floor hydrothermal mineralization: New perspectives. Econ. Geol., 88, 19351976.

Sakai, H., Gamo, T., Kim, E. -S., Tsutsumi, M., Tanaka, T., Ishibashi, J., Wakita, H., Yamano, M. and Oomori, T. (1990): Venting of carbon dioxide-rich fluid and hydrate formation in MidOkinawa Trough backarc basin. Science, 248, 10931096.

Saunders, A. D., Norry, M. J. and Tarney, J. (1991): Fluid influence on the trace element compositions of subduction zone magmas. Phil. Trans. Royal Soc. London, A. 335, 377-392.

Sawkins, F. J. (1972): Sulfide ore deposits in relation to plate tectonics. J. Geol., 80, 377-397.

Spiess, F. N. and RISE Group (1980): East Paci- 
fic Rise ; Hot springs and geophysical experiments. Science, 297, 1421-1433.

Stolper, E. M. and Newman, S. (1992): Fluids in the source regions of subduction zone magmas: Clue from the study of volatiles in Mariana Trough magmas. Geological Survey of Japan, Report, 279 (Hedenquist, J. W. ed.: Magmatic contributions to hydrothermal systems), 161-169.

Stuben, D., Stoffers, P., Cheminee, J. L., Hartman, M., McMurtry, G. M., Richnow, H. H., Jenish, A. and Michaels, W. (1992): Manganese, methane, iron, zinc, and nickel anomalies in hydrothermal plumes from Teahitia and Macdonald volcanoes. Geochim. Cosmochim. Acta, 56, 3693-3704.

Taira, A. and Pickering, K. T. (1991): Sediment deformation and fluid activity in the Nankai, izuBonin and Japan forearc slopes and trenches. In Tarney, J., Pickering, K. T., Knipe, R. J. and Gewey, J. F. eds.: The behaviour and influence of fluids in subduction zones. The Royal Society, London, 63-88.

Tamaki, K. and Honza, E. (1992) : Global tectonics and formation of marginal basins: Role of the westrn Pacific. Episode, 14, 224-230.

Taylor, B., Brown, G., Fryer, P., Gill, J., Hochstaedter, A., Hotta, H., Langmuir, C., Leinen, M., Nishimura, A. and Urabe, T. (1990): ALVINSea Beam studies of the Sumisu Rift, Izu-Bonin arc. Earth Planet. Sci. Lett., 100, 127-147.

浦辺徹郎 （1983）: 海底の熱水鉱床とユニフォーミタリ
アニズム. 海洋科学, 15, 548-553.

Urabe, T. (1987): Kuroko deposit modeling based on magmatic hydrothermal theory. Mining Geol., 37, 159-176.

浦辺徹郎 （1993）: 深層天然ガスとは・季報エネルギー 総合工学, 15, 36-43.

Urabe, T. and Kusakabe, M. (1990): Barite silica chimneys from the Sumisu Rift, Izu-Bonin Arc: Possible analog tohematitic chert associated with Kuroko deposits. Earth Planet. Sci. Lett., 100, 283-290.

浦辺徹郎 - Auzende, J. M. - Deplus, C. - Eissen, J. P. • Grimaud, D. · Huchon, P. ・石橋純一郎・上嶋 正人 - Lagabrielle, Y. - Mevel, C. ·仲 二郎 · Ruellan, E. ・田中武男・棚橋・学 (1990) : 北フィシ 一海盈中央拡大軸における熱水鉱床一ノノーチル号に よる潜水調查予報. 鉱山地質, 40, 117-124.

Usui, A., Yuasa, M., Yokota, S., Nohara, M., Nishimura, A. and Murakami, F. (1986): Submarine hydrothermal manganese deposits from the Ogasawara (Bonin) Arc, off the Japan islands. Mar. Geol., 73, 311-322.

Valette-Silver, J. N., Tera, F., Pavich, M. J., Brown, L., Klein, J. and Middleton, R. (1985) : ${ }^{10} \mathrm{Be}$ contents of natural waters. EOS, 66, p. 423.

Yuasa, M., Murakami, F., Saito, E. and W atanabe, K. (1991): Submarine topography of seamounts on the volcaninc front of the Izu-Ogasawara, Bonin, Arc. Bull. Geol. Suv. Japan, 42, 703-743.

（1995年 1 月 23 日受付，1995年 3 月 20 日受理） 